\begin{tabular}{|l|c|c|}
\hline $\begin{array}{l}\text { Word and Text } \\
\text { A Journal of Literary Studies and Linguistics }\end{array}$ & Vol. XI & $175-186$ \\
\hline
\end{tabular}

\title{
Three Ways of Looking at a Tiger: Animal Minds in Yann Martel's Life of Pi
}

\author{
Xinyi Cao
}

Shanghai Jiao Tong University

E-mail: caoxinyi@sjtu.edu.cn

\begin{abstract}
Engagement with animals is a central theme in Yann Martel's novel Life of Pi, reflected and shaped by the character-narrator Pi's reading of animal minds. The article examines attributions of minds to animals in three types of encounters with them: observation, interaction, and narration. While in childhood $\mathrm{Pi}$ tends to project human temperaments and emotions onto animals, he is forced to recognize animals' species-specific experiences as the shipwreck foregrounds his embodiment. As such, the novel introduces the logic of nonhuman psychology into narrative development, formulating an intersubjective and interspecies relationship. Furthermore, at the end of the novel, it alerts us to intellectual and therapeutic functions of animals as narrative elements through a comparison between representations of human and animal minds. The text not only identifies different forms of presence of animals in the human world, but generates insights into how narrative in general conveys and responds to complex human-animal entanglements in our reality.
\end{abstract}

Keywords: Yann Martel, Life of Pi, animal mind, anthropomorphism, empathy

'Empathy is the grand theme of our time', ${ }^{1}$ argues Frans de Waal in his 2009 book The Age of Empathy. In his view, the reach of empathy in the contemporary world requires extension, since ' $[\mathrm{t}]$ he greatest problem today, with so many different groups rubbing shoulders on a crowded planet, is excessive loyalty to one's own nation, group, or religion'. ${ }^{2}$ However, with animal studies, 'the interdisciplinary study of human-animal relations', ${ }^{3}$ flourishing in the humanities, social sciences, and natural sciences over the last decades, species has been added as another boundary that we have to cross empathetically. Most prominently, advancing the concept of 'entangled empathy', Lori Gruen proposes that 'attending to another's experience of wellbeing', ${ }^{4}$ including 'another's needs, and interests, desires, vulnerabilities, hopes, and sensitivities', ${ }^{5}$ lays the foundation upon which we may transform our treatments of animals and cultivate more caring relationships with them.

As a fundamental epistemological tool that helps make sense of complexities of reality, narrative bears particular relevance to this inquiry as thought representation

\footnotetext{
${ }^{1}$ Frans de Waal, The Age of Empathy: Nature's Lessons for a Kinder Society (New York: Harmony Books, 2009), ix.

${ }^{2}$ de Waal, The Age of Empathy: Nature's Lessons for a Kinder Society, 203.

${ }^{3}$ William S. Lynn, 'Human-Animal Studies', in Encyclopedia of Human-Animal Relationship, vol. 2, ed. Marc Bekoff (London: Greenwood Press, 2007), 672.

${ }^{4}$ Lori Gruen, Entangled Empathy: An Alternative Ethic for our Relationships with Animals (New York: Lantern Books, 2015), 3.

${ }^{5}$ Gruen, Entangled Empathy: An Alternative Ethic for our Relationships with Animals, 3.
} 
constitutes the crux of narrative structures. For the narratologist Monika Fludernik, experientiality, instead of plot, is the key factor contributing to narrativity, or the property that makes a text more or less interpreted as narrative. ${ }^{6}$ In a similar vein, Alan Palmer claims that '[n] ovel reading is mind reading', ${ }^{7}$ prioritizing mediating characters' minds as the essence of interpreting fictional narratives. However, based on 'folkpsychological continuity', ${ }^{8}$ the presumption that readers approach fictional minds with the same skills they use when attributing beliefs and desires to real people, these theories specify the mind we read as human mind, or, to use Fludernik's formulation, 'experientiality of an anthropomorphic nature'. ${ }^{9}$ Narrative is believed to centre on human or human-like experiences. Yet, as I would like to suggest later in the article, characters' minds take more varied forms, including those differing from mentalities of human beings, indicative of species-specificity. ${ }^{10}$

The novel Life of Pi (2001) by Yann Martel provides such an example. It consists of three parts. In Part One, the adult Pi Patel sketches his childhood spent in school, family, and a zoo, interwoven with a writer figure's voice describing Pi's current life pattern. In Part Two and Part Three, Pi recounts how he survives 227 days at sea after a shipwreck, accompanied by a group of animals, including a Bengal tiger named Richard Parker, and by several human beings, a cook, a sailor, and his mother respectively. Featuring encounters with animals, the life of Pi from zoo to lifeboat raises the issue of how to recognize nonhuman others. Many scholars noticed the way Martel ascribes interiority to animals. Sarah E. McFarland observes that '[ $\mathrm{t}]$ hroughout Life of Pi, Pi acts in ways that acknowledge that Richard Parker can think and feel and live a fully-fleshed life', ${ }^{11}$ through which the novel illustrates 'the kind of mutual respect between individuals'. ${ }^{12}$ Likewise, for Elisha Cohn, the work suggests that 'a recognition of separate sensory worlds might motivate human care for animals'. ${ }^{13}$

Though inspiring, these studies confine their attention to the tiger in the second part and fail to fully demonstrate the diversity and intricacies of animal minds in the novel. In what follows, I argue that there are three contexts in which Pi, the characternarrator, attributes animal minds: observation, interaction, and narration. Unlike Descartes, who influentially defined animals as natural 'automatons' for which 'we cannot at all prove the presence of a thinking soul', ${ }^{14} \mathrm{Pi}$ views animals as mindful

\footnotetext{
${ }^{6}$ Monika Fludernik, Towards a 'Natural' Narratology (London and New York: Routledge, 1996), 12.

${ }^{7}$ Alan Palmer, Social Minds in the Novel (Columbus, OH: Ohio State University Press, 2010), 21.

8 Marco Caracciolo, 'The Nonhuman in Mind: Narrative Challenges to Folk Psychology', in The Edinburgh Companion to Contemporary Narrative Theories, ed. Zara Dinnen and Robyn Warhol (Edinburgh: Edinburgh University Press, 2018), 32.

${ }^{9}$ Fludernik, Towards a 'Natural' Narratology, 26.

${ }^{10}$ Recently, some scholars in narrative studies have discussed the possibilities of representing nonhuman experiences in narrative. See, for example, David Herman, 'Storyworld/Umwelt: Nonhuman Experiences in Graphic Narratives', SubStance 40.1 (2011): 156-81; Stefan Iversen, 'Unnatural Minds', in A Poetics of Unnatural Narrative, ed. Jan Alber, Henrik Skov Nielsen and Brian Richardson (Columbus, OH: Ohio State University Press, 2013), 94-112; Lars Bernaerts et al., 'The Storied Lives of Non-Human Narrators', Narrative 22.1 (2014): 68-93; Marco Caracciolo, 'Flocking Together: Collective Animal Minds in Contemporary Fiction', PMLA 135.2 (2020): 239-53.

11 Sarah E. McFarland, 'Animal Studies, Literary Animals, and Yann Martel's Life of Pi', in The Cambridge Companion to Literature and the Environment, ed. Louise Westling (Cambridge: Cambridge University Press, 2014), 162.

${ }^{12}$ McFarland, 'Animal Studies, Literary Animals, and Yann Martel's Life of Pi', 163.

${ }^{13}$ Elisha Cohn, 'Paperback Tigers: Breaking the Zoo', Contemporary Literature 56.4 (2015): 577.

${ }^{14}$ René Descartes, 'Animals Are Machines', in Animal Rights and Human Obligations, ed. Tom Regan and Peter Singer (Englewood Cliffs, NJ: Prentice-Hall, 1976), 65.
} 
beings in all contexts. At issue is what content the minds have, what function the minds perform, and how they reflect and help shape different models of human-animal relationships. Such an investigation not only allows us to imagine and evaluate various approaches to animal subjectivity, but generates insights into the potential of narrative in general to engage with humans' entanglements with other species.

\section{Anthropomorphic Minds and Imaginary Animals}

The novel traces out Pi's early association with animals in the first part. Inserted within lengthy narratorial explanation of zoo animals' habits is a recollection of a key event that improves Pi's understanding of wild animals: his father puts a goat into the cage of a tiger and forces him to witness the tiger killing it. Blood imprinted on his memory, Pi henceforth avoids touching tigers and acquires the lesson that wild animals are 'essentially and practically removed from us'. ${ }^{15}$ Notably, considering how the whole story unfolds, the event undertakes to epitomize the pattern of Pi's lifelong interconnection with animals. In the incident, two situations in which Pi may come into contact with animals arise: one with iron bars erected between them and one without. Whereas Pi coldly watches animals from a safe distance outside the cage, he is able or even forced to establish concrete contact with nonhuman others without barriers. What accompany the opposite situations are disparate attitudes towards animals: anthropomorphic projections that assign human characteristics to animals and the view acknowledging animals' otherness. As Pi's father's instruction indicates, one is free to picture how animals possess human thoughts and desires behind the bars, but recognition of species-specific agency is a demand for sharing space with them; otherwise, one might risk losing one's life.

Throughout the book, iron bars transform either into safety precautions in the zoo or into the sea surface of the Pacific Ocean, through which Pi observes animals and detects their minds within spatial constraints. For example, Pi discerns a wide variety of emotional states of animals in the zoo: 'the stately silence of a giraffe [...] the greeting claps of a shoebill's bill; the senile, lecherous expression of a camel' $(L P, 18)$. After his father warns of animal alterity, Pi still 'fancied the rhinos' heads were hung low with sadness over the loss of one of their dear companions' $(L P, 48)$. Similar conditions exist in Part Two when he looks down the water and tracks marine creatures passing by. In his delineation, a sea turtle, flippers 'lazily turning', takes on a 'haughty and severe' $(L P, 154)$ expression. All the sentences designate animals' interiority, but the terms adopted, such as 'senile', 'lecherous', 'sadness', and 'lazily', are closely bound up with human temperament and emotions. Pi approaches animal minds in an anthropomorphic manner in effect.

For many theorists in narrative studies, thought representations ultimately contribute to the overall narrative development. In Palmer's opinion, '[characters'] beliefs, desires, and other thought processes to a great extent compose the plot'. ${ }^{16}$ Viewed in this light, it is worthwhile to examine the affordances that animal minds generate for plot, so as to comprehensively grasp their function in the narrative. Specifically, in the novel, the mentalities featuring anthropomorphism fail to intervene

\footnotetext{
${ }^{15}$ Yann Martel, Life of Pi (Orlando, FL: Harcourt, 2001), 39; hereafter $L P$ with page references in the text.

${ }^{16}$ Palmer, Social Minds in the Novel, 9.
} 
in other characters' experientiality, which are thus disassociated from the narrative progression. Pi openly claims that 'I quite deliberately dressed wild animals in tame costumes of my imagination. But I never deluded myself as to the real nature of my playmates' $(L P, 42-3)$. Treating animal minds as pure products of fantasy, Pi denies the animals in his life the status of equal agents. As a result, they retain solely exterior aspects as passive objects, including appearances, 'senile' and 'lecherous' expressions, and the posture of the head hung low.

Most significantly, the pattern and function of animal minds in these passages reveal the imaginary presence of animals in the human world. Broadly speaking, 'animals as we know them are a literary invention'. ${ }^{17}$ In the widely-discussed novella The Lives of Animals (1999) by J. M. Coetzee, the protagonist Elizabeth Costello regretfully points out: 'Man went to war with the lion and the bull, and after many generations won that war definitively. Today these creatures have no more power. Animals have only their silence left with which to confront us' ${ }^{18}$ Given Pi's motive behind the projections as well as the lack of animal actions testifying to the mental states he projects, the anthropomorphic minds to a large extent remain unverified and fictional. Therefore, they point to humans' egoistic perception instead of the real existence of animal beings. In Pi's own words, 'we look at an animal and see a mirror' $(L P, 39)$.

Furthermore, the author correlates invention of animal minds with anthropocentric preoccupations. In the zoo, animals play the role of Pi's 'playmates' and what they bear in mind is part of his game. If the boy approaches inner worlds of zoo animals for entertainment, he seeks consolation from those of marine beings. As noted, suffering complete isolation, Pi starts to perceive human emotions in the swimming behaviour of a turtle; he evaluates it as 'the first specimen of what would become a dear, reliable friend of mine' $(L P, 154)$. Later, Pi extends anthropomorphism from the turtle's mind to the capacity for human language, speaking to it: 'Go tell a ship I'm here. Go, go' ( $L P$, 155). Perfectly aware that the turtle cannot be his real friend or communicate with crew of any ship, Pi imagines the animal as an intelligent individual to keep alive the hope that he is still connected with the outside world. As such, the speculations are neither of animals in their own right nor for them. They belong to 'imaginative anthropomorphism', 'the productive activity of representing imaginary or fictional animals as similar to us'. ${ }^{19}$

Overall, the role and place of animals could be examined through the lens of the ideology discussed by John Berger. According to him, animals were relegated to the silent majority after the rise of nineteen-century capitalism. They end up 'always the observed' 20 in human society: 'The fact that they can observe us has lost all significance. They are the objects of our ever-extending knowledge'. ${ }^{21}$ In Pi's unidirectional looks, animals no longer stimulate humans' reflections on themselves and the universe by virtue of 'the parallelism of their similar/dissimilar lives'. ${ }^{22}$ Instead, they are reduced to spectacles for humans to prove knowledge and exert power.

\footnotetext{
${ }^{17}$ Mario Ortiz Robles, Literature and Animal Studies (London, New York: Routledge, 2016), 2.

18 J. M. Coetzee, The Lives of Animals, ed. Amy Gutmann (Princeton, NJ: Princeton University Press, 1999), 25.

19 John Andrew Fisher, 'The Myth of Anthropomorphism', in Readings in Animal Cognition, ed. Marc Bekoff and Dale Jamieson (Cambridge, MA: MIT Press, 1996), 6.

${ }^{20}$ John Berger, About Looking (New York: Vintage Books, 1992), 16.

${ }^{21}$ Berger, About Looking, 16.

${ }^{22}$ Berger, About Looking, 7.
} 
However, both anthropomorphism and anthropocentrism collapse when the sinking ship leaves Pi marooned with a number of animal individuals on the boat. The unusual setting opens up an alternative fashion in which humans bond with other forms of life and conceive their consciousness.

\section{Species-Specific Minds and Subjective Animals}

The physical separation between $\mathrm{Pi}$ and animals unexpectedly disappears after the shipwreck. When the Canada-bound ship sinks in the Pacific Ocean, a crewman throws Pi into a lifeboat, in which Pi encounters a zebra, a hyena, an orangutan, and a tiger named after its captor 'Richard Parker' due to a clerical error. As the human name implies, the human-animal border becomes blurred on the boat. To be precise, the paradigm of human-animal relationships evolves into equality, marked by their fragile bodies and cross-species exchanges of looks. Pi identifies the finitude and vulnerability of life in the condition of every animal, including himself: the zebra lies quietly as its '[b]ones protruded through skin and there was bleeding' $(L P, 136)$; the orangutan, $\mathrm{Pi}$ claims, heads towards the destination of 'oblivion' $(L P, 139)$; the hyena endures the 'fear of the greatest beast' $(L P, 172)$; the tiger is in dire need of food and water every day; threatened by the rough sea, fierce predators, and lack of food, Pi himself lives in constant terror. Anat Pick argues that "[c]reaturely vulnerability opens up zones of "indistinction", where species identities blur and where different beings, or creatures, are perceived as corporeal and vulnerable'. ${ }^{23}$ In the story, the awareness of shared vulnerability to death likewise demonstrates the collapse of species boundaries in Pi's eyes.

Animal gazes confirm this knowledge. As he inspects other animals, Pi finds himself simultaneously the object of their observation. For instance, he notices the hyena for the first time when '[i]t looked me in a direct, frightened way' and 'froze my blood' $(L P, 137)$. Similarly, his close yet tense relation to Richard Parker starts with an eye contact: 'when Richard Parker's amber eyes met mine, the stare was intense, cold and unflinching [...] Every hair on me was standing up, shrieking with fear' $(L P, 191)$. Exchanges of looks with animals stir intense emotions in Pi, urging him to acknowledge the strength and agency of these companions. Precisely, in Wendy Woodward's words, it is a gaze that "compels a response on the part of the human, as it contradicts any assumed superiority of the human over the nonhuman animal'. ${ }^{24}$ As the shared vulnerability and exchanges of looks suggest, on the boat is a group of individuals fighting the 'battle for life' $(L P, 149)$ in an autonomous and interconnected way.

Such a situation not only necessitates speculating on other minds, but also determines the type of access to them. Because nonhuman animals, chiefly carnivores, pose the main threat to his life, Pi must strive to understand their mental states so as to accurately predict or explain their behaviours and to survive. Mental attributions here, as analysed in detail below, thus fall into 'interpretive anthropomorphism', in which 'anthropomorphism is an inference from the animal's behavior [...] it also could be considered an interpretation of the animal's behavior or an explanation of the animal's

\footnotetext{
23 Anat Pick, 'Vulnerability', in Critical Terms for Animal Studies, ed. Lori Gruen (Chicago, London: University of Chicago Press, 2018), 414.

24 Wendy Woodward, The Animal Gaze: Animal Subjectivities in Southern African Narratives (Johannesburg: Wits University Press, 2001), 1.
} 
behavior based on the truth of the ascribed [mentalistic predicates]' ${ }^{25}$ The fact that Pi normally depends on zoological knowledge and experience in animal behaviour as the son of a zookeeper to infer animals' motivations denotes scientific neutrality of his access as well.

Understanding the nature of animals entails full consideration of both animals' experiential capacity and species alterities in the novel, as implied in Pi's father's lesson. Generally speaking, animals are still delivered through the language of human thought and action. At the beginning of Part Two, when the tiger Richard Parker swims towards the boat, the narrator relates: 'He was struggling to stay at the surface of the water' $(L P, 121)$. The verb 'struggling' serves to embody the animal's intention, emphasizing how Richard Parker exerts efforts to avoid drowning. Likewise, Pi utilizes the adverb 'impatiently' in the phrase 'huffing impatiently' $(L P, 284)$ to indicate Richard Parker's anxious and distracted state of mind. Most importantly, mindreading occurs at key transition points in the survival adventure. After Richard Parker kills the hyena, his eyes 'spoke of self-possession on the point of exploding with rage' $(L P, 191)$. Later, as Pi strains for a plan to get rid of Richard Parker, the tiger's 'friendliness and harmless intention' $(L P, 206)$ expressed through a prusten sound inspires him. Besides, during the training process, $\mathrm{Pi}$ adjusts strategies the instant he interprets the signal of 'warning' $(L P, 261)$ from the tiger. In animal writing, Eileen Christ claims, portrayal of action as meaningful, authored, and continuous delivers subjectivity to the world of animals. ${ }^{26}$ By this standard, Richard Parker appears as a tiger subject.

However, anthropomorphism does not swallow up species divergence. Building on the philosopher-biologist Jakob von Uexküll's Umwelt concept, David Herman proposes that narrative can use what he terms 'Umwelt modeling' to construct 'models of the lived, phenomenally experienced worlds of nonhuman animal themselves'. ${ }^{27}$ It is a counterfactual modelling that ascribes to animal agents 'on the basis of their distinctive sensorimotor repertoires, other-than-human perceptual discriminations, or possibilities for interaction with their surrounding environments, social as well as material'. ${ }^{28}$ For Herman, therefore, despite the fact that animal and human thought converge in essence, they differ with regard to the association between worldly environments and subjective experiences that environments help shape, or, put otherwise, the particular way an agent negotiates objective surroundings. Seen in this light, species features of Richard Parker's mind in the novel specifically manifest themselves in how the tiger defends territories and responds to loud noises and steady movements. Consistent with Uexküll's argument that territory 'represents an exclusively subjective product', ${ }^{29} \mathrm{Pi}$ regards territoriality as 'the key to [animals'] minds' $(L P, 21)$. It is based on the territorial mind that he surmises from the smell of the tiger's urine that 'Richard Parker's territorial claims seemed to be limited to the floor of the boat' $(L P, 215)$. Such a feature suggests the improbability of the tiger's attacks beyond the floor, which allows Pi to safely stay on the tarpaulin of the boat.

\footnotetext{
${ }^{25}$ Fisher, 'The Myth of Anthropomorphism', 6.

26 Eileen Crist, Images of Animals: Anthropomorphism and Animal Mind (Philadelphia: Temple University Press, 1999), 4.

27 David Herman, Narratology beyond the Human: Storytelling and Animal Life (Oxford: Oxford University Press, 2018), 140.

${ }^{28}$ Herman, Narratology beyond the Human: Storytelling and Animal Life, 139.

${ }^{29}$ Jakob von Uexküll, A Foray into the Worlds of Animals and Humans with a Theory of Meaning, trans. Joseph D. O’Neil (Minneapolis, MN and London: University of Minnesota Press, 2010), 103.
} 
What's more, someone's 'erect posture, clam demeanour, steady gaze, fearless step forward, strange roars' $(L P, 55)$ demonstrate strength and superiority for beasts in particular, on the basis of which Pi designs the scheme for training Richard Parker. In a comprehensive explanation of his training steps, Pi points out that an animal is more likely to get 'piqued, peeved, vexed, bothered, irked, annoyed' $(L P, 257)$ if trainers start to blow into a whistle and make a mild yet consistent noise. When the animal is roused, trainers should then be sure to keep eye contact with the animal so as to subsequently convey a message of aggression to it, 'to make your animal understand that its upstairs neighbour is exceptionally persnickety about territory' $(L P, 257)$. Validity of these tips presumes a set of unique properties of Richard Parker's mind, distinguishing it as an alien subject from human beings. As animal intentionality and psychology contribute to the plot development by influencing Pi's thoughts and actions, the work manages to establish a storyworld in which human and nonhuman characters cohabit.

Against the trend towards human dominance in shipwreck narratives, ${ }^{30}$ the author formulates an intersubjective and interspecies relationship. A variety of interactions between Pi and Richard Parker are presented to be the result of co-participation on the two parts. For instance, in the account of taming the tiger, first, it is Pi and Richard Parker together that produce the idea. On the surface, the decision comes from Pi's realization that '[i]t was not a question of him or me, but of him and me [...] Only if I tamed him could I possibly trick him into dying first' ( $L P, 206-7)$, but beforehand, Richard Parker already makes the sound of prusten 'to express friendliness and harmless intentions' $(L P, 206)$, displaying its cooperative intention and provoking Pi's cognitive transformation.

Secondly, both sides determine how the training proceeds. At the planning stage, while the program is generally designed around Pi's desire to live on the boat, Richard Parker's territorial mind compels him to model it more specifically as a territorial competition. Meanwhile, the animal's claim on the floor further leaves Pi with no choice but to set the upper tarpaulin as his potential target. When it comes to its execution, Pi blows the whistle to 'make him understand that I was the top tiger' ( $L P$, 211). In response, Richard Parker bares his teeth, vomits roars, and then cuffs $P i$ as well as his shield into water to send a 'warning' $(L P, 261)$ signal. After it carries out the attack several times, Pi interprets and decides to ignore the menace. He continues whistling until the tiger moans at the bottom of the boat. What the two individuals practise during the whole process is to express their intentions and to react to those of the other in turn. The training hence takes the form of cross-species intersubjective communication. In this regard, Life of Pi exemplifies what Susan McHugh terms as 'intersubjective fiction', in which 'companions of different species demonstrate no magical or otherwise supernatural powers of connection, but instead act ordinarily to live and work together successfully in unprecedented - and surprisingly hostileconditions'. ${ }^{31}$

\footnotetext{
${ }^{30}$ See more about the historical development of the shipwreck narrative in June Dwyer, 'Yann Martel's Life of Pi and the Evolution of the Shipwreck Narrative' Modern Language Studies 35.2 (2005): 9-21.

${ }^{31}$ Susan McHugh, Animal Stories: Narrating across Species Lines (Minneapolis, MN: University of Minnesota Press, 2011), 4.
} 


\section{Beyond Reference: Interpretation of Animals in Narrative}

The final part of the novel comprises a transcript of a tape and a report, which record the process and the result of a conversation held between Pi and two Japanese investigators shortly after Pi survives to come ashore in Mexico. In this meeting, Pi offers another version of his experiences at sea that replaces the animals with human beings, a story of cannibalism ${ }^{32}$ and moral degradation. Through comparing and evaluating the two stories, the three people open up a discussion on the essence and value of narrative itself. Therefore, animals no longer come into view as imaginary or subjective beings but as narrative elements. Specifically, the group interpret animals in the story from two stances. If a narrative is taken to refer to real lives as the investigators insist, it matters whether animals reasonably correspond to those in reality; if, as Pi claims, a narrative is nothing but invention, how animals contribute to our understanding of and engagement with the world is of primary concern.

Representative of most readers of the book, the two investigators evaluate the first story in terms of its faithfulness to real-life situations. The presence of animals in narrative has long resisted a literal reading in the history of literary criticism. As McHugh remarks, 'literary critics historically have rendered the animals a non-issue' by 'reading animals as metaphors, always as figures of and for the humans'. ${ }^{33}$ Therefore, it does not come as surprise that the Japanese downplay the importance of the first story by doubting the plausibility of a man living with a tiger for so many days (along with other phenomena beyond human experience such as the floating bananas and the algae island). One of them claims that '[w]e have difficulty believing it' $(L P, 372)$ and further questions Pi: 'Mr. Patel, a tiger is an incredibly dangerous wild animal. How could you survive in a lifeboat with one?' $(L P, 373)$ When they hope for words that reflect reality, they fundamentally want, as Pi summarizes, 'a story without animals' $(L P, 381)$.

Echoing the investigators, many critics of the book dwell on literalness of the represented animals when it comes to the meaning of the first story. The majority of them similarly prefer allegorical interpretations. For example, Cohn contends that 'animals are figures for fiction itself' ${ }^{34}$ because looking at animals generates a way of telling a story of surviving with vicious men. From a different angle, Florence Stratton points out that Richard Parker, displaying dazzling colours and patterns, symbolizes 'the incantatory or transcendent power of art: the imaginative truths or realities that great art encompasses'. ${ }^{35}$ Comparing the first story with the second one, James Mensch also

\footnotetext{
32 About survival cannibalism in Western culture, see Jennifer Brown, Cannibalism in Literature and Film (Basingstoke: Palgrave Macmillan, 2013), 221-9. According to Brown, '[t]ales of shipwreck victims resorting to cannibalism were relatively common in the eighteenth and nineteenth centuries, resulting in "The Custom of the Sea"' (221). One such notorious event - the attack of the Essex, an American whaler, by a sperm whale and its subsequent sinking, after which the crewmen survived in part by cannibalizing their companions' bodies - was used as source material for Herman Melville's Moby Dick (1851).

${ }^{33}$ Susan McHugh, 'Animal Farm's Lessons for Literary (and) Animal Studies', Humanimalia 1.1 (2009): 24.

${ }^{34}$ Cohn, 'Paperback Tigers: Breaking the Zoo', 579.

35 Florence Stratton, “Hollow at the Core": Deconstructing Yann Martel's Life of Pi', Studies in Canadian Literature 19.2 (2004): 10.
} 
grounds his reading in allegory. From his viewpoint, 'Pi is actually Richard Parker [...] Richard Parker here represents the animality that he cannot accept'. ${ }^{36}$

Of particular significance in the novel is how Pi alerts his audience inside and outside the storyworld to a new dimension to reading animals in response to the investigators' rejection of the first story. Instead of diverting from metaphorical to material reading as some other critics do, ${ }^{37}$ he disputes the single consideration of referential function of narrative, avoiding the 'either/or dilemma' ${ }^{38}$ in interpretations of animals in narrative. In his words, '[t]he world isn't just the way it is [...] [but] how we understand it' $(L P, 380)$, so storytelling is always 'already something of an invention' $(L P, 380)$. Put otherwise, every narrative is poetic in nature. It then becomes futile to argue how accurately narratives signify reality; we should rather examine how they enrich our conception of reality. Encountering narrative animals in this context entails the question of what reflections on facts inventing animals provokes, or, in terms of the two adventure stories Pi recounts, how themes of the story with animals differ from those of the one without.

The stark contrast between human and animal thought representation suggests the answer. For most narratologists, either characters' action or experientiality is the defining element of narrative. Traditionally, narrativity is related to action. Vladimir Propp, for instance, considers that actions 'serve as stable, constant elements in a tale, independent of how and by whom they are fulfilled. They constitute the fundamental components of a tale'. ${ }^{39}$ Against the trend, scholars of cognitive narratology such as Fludernik and Palmer argue for the core status of experientiality, as we have mentioned at the beginning of the article. In Pi's narrations, human and animal characters act in parallel. Besides sharing the beginning of a shipwreck and the end with Pi discovered alone on the beach, both stories contain three sequential killings in between: the hyena kills the zebra and the orangutan, and the tiger kills the hyena in the first one, whereas the cook kills the sailor and Pi's mother, and then Pi kills the cook in the second. Nevertheless, divergent intentions assign separate meaning to the events. In the former story, the violence arises in a pervasive mood of anxiety. Authored by the animals who struggle with 'strain' $(L P, 144)$ and 'anguish' $(L P, 147)$, the cruel conducts testify to the instinct of lives to defend themselves in a plight. In the latter story, however, the situation becomes complicated, because moral corruption constitutes one of the conditions for cannibalism. Depictions of the way the cook 'promptly butchered' ( $L P$, $386)$ the sailor and 'threw himself upon' $(L P, 387)$ the corpse undermine indifference to beings of his own kind.

\footnotetext{
${ }^{36}$ James Mensch, 'The Intertwining of Incommensurables: Yann Martel's Life of Pi', in Phenomenology and the Non-Human Animal: At the Limits of Experience, ed. Corinne Painter and Christian Lotz (Dordrecht: Springer, 2007), 140.

${ }^{37}$ See, for example, Danielle Sands, 'Animals', in The Routledge Companion to Twenty-First Century Literary Fiction, ed. Daniel O'Gormon and Robert Eaglestone (London and New York: Routledge, 2019), 200-1.

${ }^{38}$ Susan McHugh, Robert McKay and John Miller, 'Introduction: Towards an Animal-Centred Literary History', in The Palgrave Handbook of Animals and Literature, ed. Susan McHugh, Robert McKay and John Miller (Cham: Palgrave Macmillan, 2021), 2. The authors propose that we face an either/or dilemma in reading or interpretation of animals in literature, that we either read this or that literary animal as 'a metaphorical figure: as a symbol, part of a cross-species allegory in which animal life embodies ideas about human life', or as animals, 'attentive to their portrayal as an account of their own material or experiential reality' (2).

${ }^{39}$ Vladimir Propp, Morphology of the Folktale (Austin, TX: University of Texas Press, 1968), 21.
} 
Moreover, human and animal minds imbue the entire narratives with conflicting significance by framing their plots into disparate patterns. For the former story, the three deaths result from animals' natural experiences of fear and strain, while the actual turning point happens afterwards when the hostility between Pi and Richard Parker gives way to cooperation. Conversely, the kernel of the latter story takes place at its very beginning, when 'selfishness, anger, ruthless' $(L P, 391)$ propels $\mathrm{Pi}$ to stab the cook. In consequence, one is about bonding while the other alienating. The contrasting themes designate different perspectives on reality. Martel illustrates in an interview that novel or religion 'makes you suspend your disbelief [...] It's not because the facts are ignored. It's more how you interpret the facts and how much you value facts that affect the totality of your sense experience'. ${ }^{40}$ With the aid of human and animal minds, Pi present his listeners or readers two sets of subjective explanation for what happened between the shipwreck and the arrival, two facts confirmed by the Japanese investigators: $\mathrm{Pi}$, the only character for whom there is a real-world referent, survives by virtue of empathy in one account and of cruelty in the other.

Martel reveals not only the intellectual but also the emotional power of animal minds. When he finishes the second story, Pi provides the investigators with a second chance to assess the story with animals, this time changing the question "which story is reasonable?" to 'which story do you prefer?' $(L P, 398)$ Perhaps a simple aesthetic choice $^{41}$ for the investigators, it concerns one's emotional or spiritual healing for the boy. After the two audiences admit that ' $[\mathrm{t}]$ he story with animals is the better story' ( $L P$, 398), Pi cries uncontrollably. His sorrow as well as the subsequent conviction that Richard Parker is 'hiding somewhere you'll never find him' $(L P, 399)$ imply the fact that he probably never encounters any tiger on the boat and instead feels 'horrible' ( $L P$, 391 ) as the character Pi does in the second story. However, envisioning animal minds enables him to extract positive meaning from the experiences and to suppress the grief. To borrow Martel's expression, 'the empathetic imagination [...] becomes practically a psychotherapeutic tool'42 in Pi's case.

\section{Concluding Remarks}

Lorraine Daston and Gregg Mitman argue that we think with animals in two senses: 'humans assume a community of thought and feeling between themselves and a surprisingly wide array of animals; they also recruit animals to symbolize, dramatize, and illuminate aspects of their own experience and fantasies'. ${ }^{43}$ Life of Pi sheds new light on both dimensions by resorting to different forms and functions of animal minds. It explores the possibility to establish an intersubjective relationship with concrete animal beings as Pi shifts his mode of approaching thoughts of animals in his life. Additionally, the dispute between Pi and the investigators in the last part opens up a reading of animals in narrative as a vehicle for diversifying our perception of reality.

\footnotetext{
${ }^{40}$ Sabine Sielke, “"The Empathetic Imagination": An Interview with Yann Martel', Canadian Literature 177.2 (2003): 24 .

${ }^{41}$ Stewart Cole, 'Believing in Tigers: Anthropomorphism and Incredulity in Yann Martel's Life of Pi' Studies in Canadian Literature 29.2 (2004): 23.

${ }^{42}$ Sielke, “"The Empathetic Imagination”: An Interview with Yann Martel', 25.

${ }^{43}$ Lorraine Daston and Gregg Mitman, 'The How and Why of Thinking with Animals', in Thinking with Animals: New Perspectives on Anthropomorphism, ed. Lorraine Daston and Gregg Mitman (New York: Columbia University Press, 2005), 2.
} 
Transported into a rich nonhuman world by novels such as Life of Pi, readers embark on meditations on how humans co-exist with other animals in a larger biosphere. At the same time, they find the opportunity to review the potential of narrative fiction itself, how storytelling can or shall speak to the issue of cross-species relationality. As Mario Ortiz Robles concludes, '[1]iterature helps us imagine alternatives to the way we live with animals, and animals help us imagine a new role for literature in a world where our animal future is uncertain' ${ }^{44}$

\section{Bibliography}

1. Berger, John. About Looking. New York: Vintage Books, 1992.

2. Bernaerts, Lars et al. 'The Storied Lives of Non-Human Narrators'. Narrative 22.1 (2014): 68-93.

3. Brown, Jennifer. Cannibalism in Literature and Film. Basingstoke: Palgrave Macmillan, 2013.

4. Caracciolo, Marco. 'Flocking Together: Collective Animal Minds in Contemporary Fiction'. PMLA 135.2 (2020): 239-53.

5. Caracciolo, Marco. 'The Nonhuman in Mind: Narrative Challenges to Folk Psychology.' In The Edinburgh Companion to Contemporary Narrative Theories. Edited by Zara Dinnen and Robyn Warhol. Edinburgh: Edinburgh University Press, 2018. 30-42.

6. Coetzee, J. M. The Lives of Animals. Edited by Amy Gutmann. Princeton, NJ: Princeton University Press, 1999.

7. Cohn, Elisha. 'Paperback Tigers: Breaking the Zoo'. Contemporary Literature 56.4 (2015): 568-600.

8. Cole, Stewart. 'Believing in Tigers: Anthropomorphism and Incredulity in Yann Martel's Life of Pi'. Studies in Canadian Literature 29.2 (2004): 22-36.

9. Crist, Eileen. Images of Animals: Anthropomorphism and Animal Mind. Philadelphia: Temple University Press, 1999.

10.Daston, Lorraine, and Gregg Mitman, 'The How and Why of Thinking with Animals'. In Thinking with Animals: New Perspectives on Anthropomorphism. Edited by Lorraine Daston and Gregg Mitman, New York: Columbia University Press, 2005. 1-14.

11.Descartes, René. 'Animals Are Machines'. In Animal Rights and Human Obligations. Edited by Tom Regan and Peter Singer. Englewood Cliffs, NJ: Prentice-Hall, 1976. 60-6.

12.de Waal, Frans. The Age of Empathy: Nature's Lessons for a Kinder Society. New York: Harmony Books, 2009.

13.Fisher, John Andrew. 'The Myth of Anthropomorphism'. In Readings in Animal Cognition. Edited by Marc Bekoff and Dale Jamieson. Cambridge, MA: MIT Press, 1996. 3-16.

14.Fludernik, Monika. Towards a 'Natural' Narratology. London and New York: Routledge, 1996.

15.Gruen, Lori. Entangled Empathy: An Alternative Ethic for our Relationships with Animals. New York: Lantern Books, 2015.

16.Herman, David. Narratology beyond the Human: Storytelling and Animal Life. Oxford: Oxford University Press, 2018.

17. Herman, David. 'Storyworld/Umwelt: Nonhuman Experiences in Graphic Narratives'. SubStance 40.1 (2011): 156-81.

18.Iversen, Stefan. 'Unnatural Minds'. In A Poetics of Unnatural Narrative. Edited by Jan Alber, Henrik Skov Nielsen and Brian Richardson (Columbus, OH: Ohio State University Press, 2013), 94-112.

\footnotetext{
${ }^{44}$ Robles, Literature and Animal Studies, xi.
} 
19.Lynn, William S. 'Human-Animal Studies'. In Encyclopedia of Human-Animal Relationship. Volume 2. Edited by Marc Bekoff. London: Greenwood Press, 2007. 672-4.

20.Martel, Yann. Life of Pi. Orlando, FL: Harcourt, 2001.

21.McFarland, Sarah E. 'Animal Studies, Literary Animals, and Yann Martel's Life of Pi'. In The Cambridge Companion to Literature and the Environment. Edited by Louise Westling. Cambridge: Cambridge University Press, 2014. 152-65.

22.McHugh, Susan. 'Animal Farm's Lessons for Literary (and) Animal Studies'. Humanimalia 1.1 (2009): 24-39.

23.McHugh, Susan. Animal Stories: Narrating across Species Lines. Minneapolis, MN: University of Minnesota Press, 2011.

24.McHugh, Susan, Robert McKay and John Miller. 'Introduction: Towards an Animal-Centred Literary History'. In The Palgrave Handbook of Animals and Literature. Edited by Susan McHugh, Robert McKay and John Miller. Cham: Palgrave Macmillan, 2021. 1-11.

25.Mensch, James. 'The Intertwining of Incommensurables: Yann Martel's Life of Pi'. In Phenomenology and the Non-Human Animal: At the Limits of Experience. Edited by Corinne Painter and Christian Lotz. Dordrecht: Springer, 2007. 135-48.

26.Palmer, Alan. Social Minds in the Novel. Columbus, OH: Ohio State University Press, 2010.

27.Pick, Anat. 'Vulnerability'. In Critical Terms for Animal Studies. Edited by Lori Gruen. Chicago and London: University of Chicago Press, 2018. 410-23.

28.Propp, Vladimir. Morphology of the Folktale. Austin, TX: University of Texas Press, 1968.

29.Robles, Mario Ortiz. Literature and Animal Studies. London and New York: Routledge, 2016.

30.Sielke, Sabine. "“The Empathetic Imagination": An Interview with Yann Martel'. Canadian Literature 177.2 (2003): 12-32.

31.Stratton, Florence. "'Hollow at the Core": Deconstructing Yann Martel's Life of Pi'. Studies in Canadian Literature 19.2 (2004): 5-12.

32.Uexküll, Jakob von. A Foray into the Worlds of Animals and Humans with a Theory of Meaning. Translated by Joseph D. O'Neil. Minneapolis, MN and London: University of Minnesota Press, 2010.

33. Woodward, Wendy. The Animal Gaze: Animal Subjectivities in Southern African Narratives. Johannesburg: Wits University Press, 2001.

\section{Trei moduri de a privi un tigru: minți de animale în romanul lui Yann Martel Life of Pi [Viața lui Pi]}

\section{Rezumat}

Tema centrală a romanului lui Yann Martel Life of Pi [Viaţa lui Pi] este lumea animalelor, așa cum este reflectată și configurată de către personajul-narator Pi prin citirea minții animalelor. Articolul examinează cum funcționează mintea animalelor în trei tipuri de intersecții: observare, interacțiune și narațiune. Copil fiind, Pi tinde să proiecteze temperamente și emoții umane asupra animalelor. El e forțat să recunoască experiențe ale animalelor, specifice speciei lor, așa cum naufragiul prefigurează devenirea sa. Astfel, romanul introduce psihologia logicii nonumane în desfăşurarea acțiunii, formulând o relație intersubiectivă dintre specii. Mai mult, la finalul romanului, ne aduce în prim-plan funcții intelectuale și terapeutice ale animalelor ca elemente narative printr-o comparație dintre reprezentări ale minții umane și animale. Textul nu doar că identifică diverse forme prin care animalele sunt prezente în lumea umană, dar și generează perspective asupra modului în care narațiunea transmite și răspunde la interacțiunile complexe dintre uman și animal. 